\title{
1990-LUKUA JÄLJITTÄMÄSSÄ
}

\author{
Kriittisen diskurssianalyysin tavoite ei ole olla kriittinen per se, vaan \\ auttaa näkemään oman ajan neutraalistunutta puhetta, sen hegemonisoi- \\ tuneita diskursseja, kirjoittaa Erja Kolari. Hän analysoi Aikuiskasvatus- \\ lehden pääkirjoitukset 1990-luvun ajalta. Arvojen muutos näkyy niissä \\ selkeästi. Vuosikymmenen alun tasa-arvoa ja yhteisvastuuta henkivästä \\ linjauksesta lehti siirtyi humaanien äänenpainojen kautta markkina- \\ arvojen maailmaan. Vuosikymmenen lopulla sivistyksellinen tasa-arvo \\ vilahti enää sivulauseessa ja jätti "alibimuistamisen" maun.
}

\section{ERJA KOLARI}

A jatus jäljittää aikakauden henkeä ja senmuutoksia tekstien kautta oli lähtökohtana syksyllä 2001 tarkastetussa pro gradussani, jossa analysoin Aikuiskasvatuksen pääkirjoituksia 1990-luvulla. Suomalaisen yhteiskunnan ja työelämän kokemat muutokset olivat 1990luvulla perinpohjaisia. Muutokset olivat suuria myös koulutuskentällä, jossa alettiin kilpailla asiakkaista. Yksilö ja yksilöllisyys nousivat uusiksi iskusanoiksi, koulutus ja kouluttaminen korvautuivat oppimisen käsitteellä. Halusin katsoa, kuinka Aikuiskasvatuksen pääkirjoitusten agendalla muutoksiin suhtauduttiin ja millä eri tavoilla muutokset niissä näkyivät. Perusteluna tutkimukselle oli lehden oma yhteiskunnallista kantaaottavuutta korostava tehtävämäärittely. Pääkirjoituksilta journalistisena lajityyppinä odotetaan niinikään kantaaottavuutta, joten ne sopivat hyvin aineistoksi yhteiskunnallista näkökulmaa etsivään tutkimukseen. Tutkimusaineiston muodostivat yhteensä 37 pääkirjoitusta.

Mitä tuoreessa muistissa olevalla 1990-luvulla sitten oikein tapahtui? Taloudelliset, poliittiset ja kulttuuriset muutokset kietoutuvat lähihistorian perspektiivissä aina toisiinsa vaikeasti eriteltäväksi vyyhdeksi. Koulutuksessa tämä tarkoittaa esimerkiksi sitä, että tasa-arvopolitiikkaan perustuvan valtiollisen koulutusjärjestelmäideaalin väistymiselle 1990-luvulla voidaan esittää taloudellisia perusteita, mutta sitä voidaan myös pitää myöhäiseksi moderniksi tai postmoderniksi luonnehditun ajan ilmiönä. 1990-luvun monisyistä muutosta alettiin tämän diskurssianalyyttisen tutkimuksen tarpeisiin jäsentää muodostamalla tutkimuksen kontekstiksi kolme 1990-lukua tyypit- tävää teoriakehystä. Uloimman kehyksen alla hahmotettiin puhetta modernista ja postmodernista 1990-luvun kulttuurisen muutoksen selittäjänä. Sisemmän kehyksen alla referoitiin konkreettisempaa puhetta hyvinvoinnista ja lamasta sekä lopuksi sisimmän kehyksen alla edellisiin kehyksiin kiinnittyvää koulutuspuhetta. Tutkimus oli teorialähtöinen nimetessään 1990-

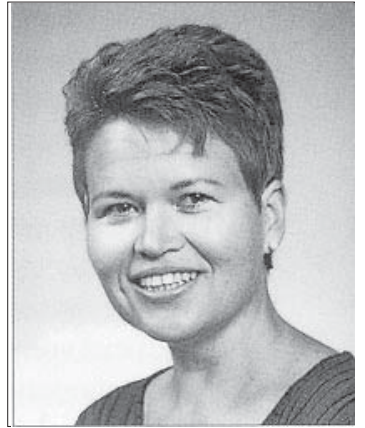

Erja Kolari luvut muutokset tutkimuksen lähtökohdaksi ja odottaessaan aineiston peilaavan näitä muutoksia.

Diskurssianalyyttisen tutkimukseen kuuluu kehittää tutkimusspesifejä metodeja. Muodosti omassa tutkimuksessani käytännön työkaluiksi kehysteorioita kiteyttävien käsiteparien taulukot ja metodiksi taulukkojen avulla luennan. Uloimman kehyksen alla tarkastelin moderni- ja postmoderni-otsikoiden alla mm. vastinpareja kansalaisuus vs. asiakkuus sekä kollektiivisuus vs. yksilöllisyys. Vastinparien avulla oli mahdollista tutkia, milloin ja missä yhteydessä postmoderni yksilöllisyys ja asiakkuus astuivat Aikuiskasvatuksen pääkirjoitusten agendalle syrjäyttäen niissä tutkimusjakson alkupuolella vallinnutta kollektiivisuutta ja kansalaisuutta. Edelleen oli mahdollista tutkia, millaisia koulutuspoliittisia ja maailmankuvallisia muutoksia termien esiintymisvaihteluihin sisältyi. Vastinparit toimivat avaimina, joiden avulla tekstiä oli mahdollista analysoida eri näkökulmista ja lopulta koostaa havaintoja 
yhteen muutoksen olemusta ja suuntaa hakien.

Sisemmän kehyksen alla tarkasteltua hyvinvointipuhetta varten koostettiin taulukko, jonka otsikkovastinpareina olivat perinteinen hyvinvointivaltion ohjelmakieli sekä sitä 1990-luvulla haastamaan noussut markkinoistumisen ohjelmakieli. Jälkimmäisen määritettiin sisältävän niin uusliberalista perua olevaa ainesta kuin epäpoliittisempana pidettävää postmodernia ajanhenkeäkin ilman että erontekoa oli useinkaan mahdollista tehdä. Termi ohjelmakieli valittiin kuvastamaan uuden diskurssin ohjelmakielenomaista leimaa, sillä kyse oli terminologiasta, jota diskurssissa toimijat kuin yhteisestä sopimuksesta alkoivat 1990-luvun kuluessa yhä vakiintuneemmin käyttää. Siinä missä hyvinvointivaltion ohjelmakieli oli painottanut mm. universaaleja oikeuksia, tasa-arvoa, edistystä ja kansalaisuutta eli uloimmassa kehyksessä tarkasteltuja moderneja piirteitä ja arvoja - puhui uusi markkinoistumisen ohjelmakieli yksilön oikeuksista, julkisen ja yksityisen rajanvedosta, paikallisuudesta, joustavuudesta, kannustavuudesta ja asiakkuudesta. Siinä missä edellinen näki laman uhkana, arvotti jälkimmäinen niukkuutta hyveenä promovoiden sopeutumisen välttämättömyyttä. Säätelyn sijaan kannatettiin nyt kilpailua jne.

Teoriakehyksiin sisällytettiin myös ristiriitaisia tulkintoja käytetyistä ja tutkittavista käsitteistä. Onhan mm. postmoderni taipunut moneksi ja sitä on arvotettu myönteisesti tai kielteisesti näkökulmasta ja käyttäjästä riippuen. Myös Aikuiskasvatuksen pääkirjoituksissa ilmeni sekä postmodernia kehitystä hyväksyviä että sitä tuomitsevia käsityksiä. Tutkimuksessa todettiin postmodernin käsitteen kuluneisuus, mutta myös sen ilmeinen hedelmällisyys, sillä tämänkin aineiston analyysi sai vauhtia juuri laveasta perusjäsennyksestä moderni-postmoderni.

Edellisiin kehyksiin kiinnittyvää koulutusdiskurssin muutosta analysoitiin omassa taulukossaan asettamalla vastakkain otsikot koulutus hyvinvointivaltiossa ja koulutus markkinoistumisen ajassa. Siinä missä koulutus tunnettuja 1990-luvun koulutusanalyysejä mukaillen tapahtui aiemmin palkkatyön yhteiskuntaan ja elinikäisille työurille, alkoi se markkinoistumisen ajassa tapahtua vapaa-ajan ja kulutuksen yhteiskunnassa globaaleille, pätkittäisille työurille. Siinä missä koulutuksen tavoitteina ennen oli ollut tasa-arvo ja integraatio, oli sen tavoitteina nyt eronteko, kilpailu ja menestys. Asiakkuuden astuminen kansalaisuuden sijaan tapahtui myös koulutuksen kehyksessä ja asiakas-kuluttajalla todettiin myös koulutuksen muuttuneessa diskurssissa olevan monia uusia oikeuksia ja vastuita kansalaiseen verrattuna. Asiakkuuden nähtiin edellyttävän uudenlaista aktiivista toimijuutta, mikä oli hyvin erilaista kuin kansalaisuuden perusteella nautittavat (passiiviset) perusoikeudet.

Tärkeimmän metodisfilosofisen esikuvan tutkimukselle antoi brittiläinen kriittisen diskurssianalyysin kehittäjä Norman Fairclough, joka on kehottanut kiinnittämään huomiota teksteihin muutoksen herkkinä mittareina. Mikään puhe ei tapahdu tyhjiössä, vaan jokainen puheenvuoro on sidoksissa aikaansa ja paikkaansa. Yhteiskunnalliset ja kultturiset muutokset, jotka ovat vasta alullaan tai sekavia, näkyvät Fairclough'n mukaan diskurssien sekamuotoisuutena, hybrididiskursseina. Esimerkiksi ilmitasoltaan postmodernia vapautta ja markkinoita promovoiva teksti voikin tarkemmassa tarkastelussa olla kiinni moderneissa, kiinteyttä ja kattavuutta vaalivissa ideaaleissa, mikä tuottaa tekstiin tiettyä ristiriitaisuutta ja tulkinnallista vaikeaselkoisuutta. Fairclough'n mukaan on itse asiassa aikalaiskulttuuriin kuuluvaa, että teksteissä on erilaisista ideologioista juurista kumpuavaa sekamuotoisuutta ja dynaamisuutta.

Fairclough'n teorioita edellä mainittuihin kehysteorioihin yhdistämällä oli mahdollista havainnollistaa Aikuiskasvatuksen pääkirjoitusten muutoksia erilaisina diskursiivisena juonteina. Tutkimusjakson aloittavat pääkirjoitukset olivat vielä melko puhtaasti kiinni sellaisessa modernin tunnusmerkistöä kantavassa maailmankuvassa, jota edustavat lausumat oli luontevaa nimetä edistysdiskurssiksi. Suomalaisen aikuiskasvatuksen odotushorisontissa näkyi vain suhteellisen pieniä pilviä ja jatkuvasti laajenevan koulutuspolitiikan aika näkyi luottamuksena oman alan kehitykseen valtiovallan suojeluksessa. Ekspansiivisen koulutusjärjestelmän aika oli kuitenkin 1990luvun alussa tulossa tiensä päähän; syynä ja nimittäjänä ennen muuta lama, joka särki totutut rakenteet ja ajatusmallit. Aikuiskasvatuksen alalla koettiin monia kolhuja, mikä näkyi pääkirjoituksissa ennen niin säröttömän koulutususkon epäilyinä ja uudenlaisena kitkeryytenä valtiovaltaa kohtaan.

Tätä muuttunutta tilannetta pettyneesti tai epäillen arvottavat lausumat nimettiin edistysepäilyn diskurssiksi. Mainittakoon tässä yhtey- 
dessä, että kun yhtenä tutkimusperusteena oli tuotu esiin aikuiskasvatustieteen ja Aikuiskasvatuksen omien tehtävämäärittelyjen mukainen käytännönläheisyys ja kantaaottavuus, näyttivät nämä ohjelmalliset piirteet toteutuvan vain viiveellä laman synnyttämän suurtyöttömyyden kommentoinnissa. Työttömyyttä alettiin kommentoida vasta laajamittaisen työllisyyskoulutuksen kommentoinnin kautta sävyn ollessa tällöin epäilevä. Niinikään hyvinvointivaltion kohtaloa pohtivia lausumia esiintyi syvimmänkin laman vuosina 1992-1994 vain yksittäisesti.

Laman voi arvioida vauhdittaneen ja oikeuttaneen sellaista postmodernien arvojen tai postmodernin ajanhengen mukaista kehityskulkua, joka oli ilmeisesti ottamassa paikkaansa muutenkin. Niinpä sellaisten yleisjulkisuuteen nopeasti vakiintuneiden käsitteiden kuin kilpailu, laatu, asiakkuus ja menestys voi katsoa kuuluvan markkinoistumisen ohjelmakieleen, jolla on juurensa niin postmodernismissa kuin uusliberalistisessa talouskehityksessäkin. Yhä useammilla elämänaloilla vakiintui joka tapauksessa 1990-luvulla tapa tarkastella asioita alun perin talouskielestä tutuilla termeillä, eivätkä Aikuiskasvatuksen pääkirjoitukset yhtenä osajulkisuuden areenana muodostaneet suurta poikkeusta yleisjulkisuuden tilanteeseen. Postmoderneja arvoja kuten yksilöllistymistä, joustavuutta ja valinnan vapautta myönteisesti arvottavat lausumat hahmotettiin teksteistä uuden ajan diskurssina. Siinä missä edistysepäilyn diskurssissa suhtauduttiin muutokseen epäillen, toivotettiin uuden ajan diskurssissa muutos tervetulleeksi, oli se sitten postmoderniksi nimettävää arvostusten muuttumista tai uusliberalistisen kielenkäytön vakiinnuttamaa puhetta yksilöllisten vapauksien puolesta.

Neljäntenä diskurssityyppinä aineistosta paikannettiin Fairclough'n teorioiden mukainen diskurssien sekoittuminen, joka sisälsi eri tavoin painottuneita yhdistelmiä edistysdiskurssista, edistysepäilyn diskurssista ja uuden ajan diskurssista. Esimerkiksi edistysdiskurssin alla kotonaan olleet sivistysdiskurssin vuorosanat kävivät 1990-luvun alkuvuosien jälkeen pian yhä harvinaisemmiksi, vaikka ne eivät koko tutkimusjaksolla täysin kadonneetkaan. Jos sivistyksellistä tasaarvoa vaaditaan enää yksittäisenä lausumana markkinoistumisen arvoja henkivän tekstin sisällä, se jättää helposti alibimuistamisen maun. Tekstissä voi tällöin paikantaa erilaisia filosofisia juuria edustavien diskurssien kamppailun elintilas- ta, jolloin voidaan puhua diskurssien sekoittumisesta tai hybrididiskursseista. Hegemonia-asemaan pyrkivä uusi diskurssi tekee vanhan diskurssin vuorosanoista vähitellen lainsuojattomia, jolloin ne käyvät liki mahdottomiksi käyttää. Tällä perusteella näyttäisi ymmärrettävältä, etteivät sellaiset sanat kuin tasa-arvo, edistys tai demokratia enää mahtuneet 1990-luvun lopun todellisuuteen, kun niillä ei ollut enää hegemoniadiskurssin antamaa selustatukea.

Diskurssien muuntumisen analysointi auttaa myös ymmärtämään miksi etenkin tietävää kirjoitusotetta edellyttävä pääkirjoitus paljastaa niin helposti ikänsä. Se joutuu tiivistäessään ja kommentoidessaan väistämättä käyttämään aikansa iskusanoja, jotka jo yhden vuosikymmenen sisällä saattavat muuttua epäilyttäviksi. Sanat ja teemat vaihtuvat. Tutkimusjakson loppupuolella ei olisi voinut enää tavata tutkimusjakson aloittavaa pääkirjoitusta, jossa "meitä suomalaisia" velvoitettiin sivistyksen nimissä lisäämään lukutaitovientiämme kehitysmaihin, vaan 1990-luvun lopun pääkirjoitusten kansainväliset viittaukset keskittyivät hyvin erilaiseen aihepiiriin - EU-yhteistyöhön - huipentuen tutkimusjakson toiseksi viimeiseen kirjoitukseen Suomesta EU-puheenjohtajamaana. Näin tutkimusjakson alku- ja loppupäätä edustavat kirjoitukset voi havainnollisesti nähdä myös kirjoituksina kahdesta erilaisesta Suomesta.

Mainittakoon, että vaatimusten ja ponsien esittäminen pääkirjoituksissa hiipui edistysdiskurssin hiipuessa ja tilalle tuli varovaisempi ja moniselitteisempi postmoderni esitystapa, jolle ironiakaan ei ollut vierasta. Muutoksissa oli siten kysymys paitsi asiasisällön myös esitystavan ja tyylin muutoksista. Niin teemat kuin sanomisen tyylikin kertovat ajastaan. Tuloksena näytti olevan se, että paatos hävisi ja etäisyyttä antava ironinen ilmaisuvaranto juurtui tutkimusjakson loppupuolella lehden pääkirjoituksiin.

Tutkimusjakson alussa vallitsi sivistyksellisestä tasa-arvosta huolta kantava diskurssi, jonka lama ja postmoderni ajanhenki sittemmin haastoivat yleisen markkinoistumiskehityksen myötä. Siinä missä tutkimusjakson alussa koulutuspuhe oli vielä tasa-arvon asialla, selätti sen tutkimusjakson loppupuolelle puhe koulutuksesta menestystekijänä. Tutkimusjakson loppua kohti vahvistui aikuiskasvatuksen uusi professionaalinen ja manageriaalinen diskurssi, jossa pohdittiin alan erityiskysymyksiä ilman yleismaailmal- 
lista huolenpitoa sivistyksestä ja koulutuksesta. Tällaisen tilanteen voi nähdä vastanneen 1990luvun yleisjulkisuuden tilannetta, jossa laman tuottama yhteiskunnallinen polarisoituminen vähitellen hiljaisesti hyväksyttiin.

\section{AIKUISKASVATUS}

\section{"EUROMENESTYJIEN" ASIALLA}

1990-luvun polarisoitumiskehitystä tutkivissa teorioissa on piirretty esiin mm. kolmijako euromenestyjiin, sinnittelijöihin ja putoajiin. Aikuiskasvatuksen pääkirjoitusten saattoi tällaisen jaottelun valossa nähdä positioineen itsensä entistä selkeämmin ensiksi mainitun ryhmän asialle. Kun puheen fokus on laadussa, tiedon jalostumisessa, johtajuudessa, konsultoinnissa tai arvioinnin problematiikassa on viitekehys sellainen koulutetun eliitin viitekehys, jossa koulutus on menestystekijän roolissa niin yksilön, organisaation kuin yhteiskunnankin kannalta. Puhe koskee silloin vain välillisesti pätkätyön varassa sinnittelevää (tieto)yhteiskunnan jäsentä puhumattakaan sen pudokkaasta. Tällaisen puheen voi nähdä myös sukupuolittuneena, sillä pätkätyöläisyys on leimallisesti naisen osa.

Tutkimusjaksoon kuuluu kehityskulku, jossa luovuttiin näkemästä aikuiskasvatus lääkkeenä mitä moninaisimpiin yhteiskunnallisiin ongelmiin. Sen sijaan sopeuduttiin yhteiskunnalliseen kehitykseen ja joustavuutta arvona alettiin promovoida. Työn kuormittavuuden ja tietointensiivisyyden kasvu ovat 1990-luvun työelämässä osaltaan lisänneet organisaatioiden kehittäjien reflektiotarpeen tukea ja tähän tarpeeseen voi pääkirjoitusten nähdä vastanneen yhä professionaalisemmin tutkimusjakson loppupuolella. Kehityksessä voi nähdä myös heijastusta aikuiskasvatustieteen aseman vakiintumisesta, joka eteni 1990-luvun aikana lamakolhuista huolimatta.

Taulukkotyökalun käytöllä oli mahdollista havaita, kuinka diskurssit niin ennen kuin nytkin paikantuvat tiettyjen supersanojen liepeille. 1990luvun loppua kohti vakiintunut koulutusdiskurssi kiertyi etenkin oppimisen käsitteen ympärille (oppimisyhteiskunta, elinikäinen oppiminen, työssä oppiminen). Oppimisvastuun luovuttaminen yksilöille oli osa uutta ajanhenkeä, jossa yksilöllä oli lupa ja vastuu menestyä. Myös suosikkitermi arviointi kytkeytyi oppimisen käsitteeseen. Ristiriitoja ja diskurssien sekoittumista nähtiin aineistossa silloin, jos omaehtoista toimijuutta implikoi- vaan termiin, kuten elinikäinen oppiminen, kytkettiin filosofisesti muuta kuten kattavien kontrollijärjestelmien vaatimuksia, kuten tutkimusjakson alkupuolella tapahtui. Päätelmänä oli tällöin se, että uuden ajan airuina olevat yksittäiset sanat ja ideat olivat vasta ikään kuin maistelussa, jossa niitä sovitettiin vanhaan, edistysdiskurssin leimaamaan kehykseen. Lopputulos on tällöin erilaisten diskurssien risteysasema, hybrididiskurssi. Supersanat ovat kuin jäävuoren huippuja, jotka kuljettavat mukanaan kokonaisia maailmanselityksiä, mikä tekee niiden etymologisesta tutkimuksesta hedelmällisen.

Kriittisen diskurssianalyysin tavoite ei ole olla kriittinen per se, vaan auttaa näkemään oman ajan neutraalistunutta puhetta, sen hegemonisoituneita diskursseja. Tällöin on helpompi nähdä vaihtoehtoja ja halutessa kyseenalaistaa itsestäänselvyyksiä. Nykyaika on moninaistanut mediakanavia, mutta kanavat useinkin monistavat samaa. Tutkittua aineistoa jäsennettiin myös arviolla, että aikuiskasvatuksen sopeutumisen perintöä kantavat kirjoitukset olivat tutkimusjaksolla olleet pääroolissa, vaikka aikuiskasvatuksella on olemassa myös valtavirtaa haastavaa ja asiaintiloja kyseenalaistavaa perinnettä. Jälkimmäistä perinnettä edustavia lausumia esiintyi aineistossa lähinnä lamanjälkeisinä vuosina 1995-97, jolloin esiin tuotiin melko radikaalejakin, aikuiskasvatuksen syvintä tarkoitusta ja aikuiskasvatuksen omaa välttämättömyyttä pohtivia yksittäisiä lausumia.

Sata vuotta vanhan uutistekstin humoristisuus on helppo nähdä, mutta olemme sokeita oman aikamme tyypillisyyksille. Yksi tämän tutkimuksen virike oli jäsentymätön ihmettely tekstien vanhenemisen syistä: 1990-luvun alun Aikuiskasvatuksen edistysuskoa huokuva pääkirjoitus tuntui "mahdottomalta" vajaat kymmenen vuotta myöhemmin, mutta oli vaikea sanoa, mistä vanhahtavuus tarkasti sanoen johtui. Tämä tutkimus auttoi osaltaan näkemään, miksi tekstit ovat aikansa lapsia ja miten ne käyttävät aikansa diskurssin vuorosanoja. Emme enää vuosituhannen vaihduttua ole pitkään aikaan vakavissamme puhuneet "kehityksen edistämisestä", mutta puhummeko muutaman vuoden kuluttua enää meille nyt tärkeillä vuorosanoilla ja mitkä ne ovat?

Kolari, Erja (2001) Aikuiskasvatus-lehden pääkirjoitukset 1990-luvulla. Diskurssianalyyttinen tutkimus muutosteeman näkökulmasta. Aikuiskasvatustieteen pro gradu. Helsingin yliopiston Kasvatustieteellinen tiedekunta. 